\title{
Spectrophotometric Determination of Bismuth in Lead-Base and Tin-Base Alloys
}

\author{
Bruce B. Bendigo, Rosemond K. Bell, and Harry A. Bright
}

\begin{abstract}
A method is described for the determination of bismuth in lead-base and tin-base alloys. Tin, arsenic, and antimony are volatilized as the bromides from a perchloric acid solution. The bismuth is then precipitated as the oxychloride in a perchloric-nitric acid solution. The precipitate is dissolved in nitric acid, and the bismuth is treated with thiourea to form a yellow complex. The absorbancy of the colored solution is measured with a filter photometer at approximately 425 millimicrons, and the amount of bismuth is read from a curve prepared by treating known amounts of bismuth with thiourea. An accuracy of \pm 0.002 percent of bismuth is indicated for lead-base and tin-base alloys containing from 0.02 to 0.10 percent.
\end{abstract}

\section{Introduction}

Bismuth in lead-base and tin-base alloys can be precipitated as the oxychloride or as the carbonate, subsequent to an alkali-sulfide treatment to remove tin, antimony, and arsenic. This method is not satisfactory in accurate work because bismuth sulfide is slightly soluble in alkali sulfides or in mixtures of the alkali sulfides and hydroxides [1]. ${ }^{1}$ If there is an appreciable amount of lead sulfide, as with lead-base alloys, some insoluble lead sulfate is usually formed when the sulfide precipitate is treated with nitric acid or a mixture of hydrochloric and nitric acids, and this interferes in the subsequent determination of bismuth.

The internal electrolysis method [2] has been used to separate bismuth and copper in solutions of leadbase and tin-base alloys. By this method the deposition of bismuth in a lead-base alloy is incomplete unless the amount of copper equals or exceeds that of bismuth, and there is considerable difficulty in obtaining adherent deposits of bismuth and copper in tin-base alloys, probably because of the hydrofluoric acid required to keep the tin in solution.

Tin, antimony, and arsenic can be removed as the volatile bromides from a sulfuric acid solution [3]. However, the solubility of tin in concentrated sulfuric acid makes it difficult to determine when all of the tin has been removed. In alloys containing considerable lead, low values for bismuth may be obtained as some bismuth is carried down with the lead sulfate [1].

After the removal of the tin, antimony, and arsenic by any of these methods, the bismuth may be precipitated as the oxychloride and the precipitate weighed, or bismuth may be precipitated as the carbonate, ignited, and weighed as bismuth trioxide, $\mathrm{Bi}_{2} \mathrm{O}_{3}$, or the precipitate of bismuth oxychloride, $\mathrm{BiOCl}$, may be dissolved in a suitable acid and bismuth determined photometrically. Mahr [4] developed a thiourea-photometric method in which a soluble yellow bismuth-thiourea complex is formed. A modification of this method was proposed by Tompsett [5].

\footnotetext{
${ }^{1}$ Figures in brackets indicate the literature references at the end of this paper.
}

A tentative ASTM standard, E46-50T, [6] for the determination of bismuth in lead-base and tin-base solder metal and white-metal bearing alloys, calls for the separation of tin, antimony, and arsenic as the volatile bromides from a perchloric-phosphoric acid solution and the measurement of the absorbancy of the bismuth-thiourea complex in the residual solution at approximately $440 \mathrm{~m} \mu$. However, if copper exceeds the maximum permissible limit of 0.5 percent, this method cannot be used.

The limitations of these several methods led to the development of the procedure described in section III. In the proposed method the sample is dissolved in a mixture of hydrobromic acid and bromine, nitric and perchloric acids are added, and tin, antimony, and arsenic are removed as the volatile bromides. Bismuth in the residual solution is precipiitated as the oxychloride. The precipitate is dissolved in nitric acid, and the bismuth is determined photometrically with thiourea at approximately 425 $\mathrm{m} \mu$.

\section{Apparatus and Reagents}

\subsection{Apparatus}

A photoelectric colorimeter of the Fisher type was used in this work. The absorption cells were matched test tubes (approximately $20 \mathrm{~mm}$ in diameter and $80 \mathrm{~mm}$ long). Measurement of the absorbancy of the solution was made with a filter having an absorption peak at approximately $425 \mathrm{~m} \mu$.

\subsection{Reagents}

Hydrobromic acid-bromine mixture. Add $10 \mathrm{~m}$ of bromine to $100 \mathrm{ml}$ of hydrobromic acid $48 \%$, Dilute ritric acid $(1+1)$. Add $500 \mathrm{ml}$ of nitri acid (sp gr 1.42) to $500 \mathrm{ml}$ of water.

Hydrobromic acid $(48 \%)$.

Dilute ammonium hydroxide $(1+2)$. Add $100 \mathrm{mi}$ of ammonium hydroxide ( $\mathrm{sp} \operatorname{gr} 0.9$ ) to $200 \mathrm{ml}$ of water.

Dilute hydrochloric acid $(1+9)$. Add $10 \mathrm{ml}$ of hydrochloric acid (sp gr 1.18) to $90 \mathrm{ml}$ of water. Thiourea solution $(5 \%)$. Dissolve $5.00 \mathrm{~g}$ of thiourea, $\left(\mathrm{NH}_{2}\right)_{2} \mathrm{CS}$, in water. Dilute to exactly 100 $\mathrm{ml}$ and filter without washing. Prepare this solution daily as needed. 
Standard bismuth nitrate solution $(1 \mathrm{ml}=0.1 \mathrm{mg}$ Bi). Transfer $0.1000 \mathrm{~g}$ of high-purity bismuth to a $250-\mathrm{ml}$ beaker and add $10 \mathrm{ml}$ of dilute nitric acid $(1+3)$. Heat gently to dissolve the sample and to expel brown fumes. Cool, transfer to a 1-liter volumetric flask, and dilute to the mark with dilute nitric acid $(1+9)$.

\section{Procedure}

The weight of sample taken for analysis should be such that the bismuth content is approximately 1 to $10 \mathrm{mg}$. The optimum weight of bismuth is from 2 to $5 \mathrm{mg}$. Transfer the sample to a $250-\mathrm{ml}$ widemouthed Erlenmeyer flask and, in a well-ventilated hood, add the hydrobromic acid-bromine mixture. For a $2-\mathrm{g}$ sample use approximately $25 \mathrm{ml}$ of the mixture and for $7 \mathrm{~g}$ use approximately $60 \mathrm{ml}$. Carry a blank through all of the operations of the procedure. Cover the flask and heat gently, avoiding excessive loss of bromine, until the sample is in solution. Cool, add $5 \mathrm{ml}$ of dilute nitric acid $(1+1)$, and cover. Heat gently until a reaction begins, indicated by effervescence, and then remove from the heat. Cool, add 15 to $25 \mathrm{ml}$ of perchloric acid $(70 \%)^{2}$ and heat over a free flame with constant rotation until the perchloric acid refluxes on the wall of the flask. ${ }^{3}$ Cool, wash the wall of the flask with $10 \mathrm{ml}$ of hydrobromic acid and continue the heating and agitation until the perchloric acid refluxes as before. If the solution is turbid, continue the addition of hydrobromic acid and the heating until a clear solution is obtained, which indicates complete expulsion of tin, antimony, and arsenic. Cool, add $25 \mathrm{ml}$ of water and $10 \mathrm{ml}$ of dilute nitric acid $(1+1)$. If the solution is turbid at this point, heat until the solution clears. Transfer the solution to a $600-\mathrm{ml}$ beaker and dilute to approximately $100 \mathrm{ml}$.

Add dilute ammonium hydroxide $(1+2)$ drop by drop from a burette while constantly stirring the solution until a faint opalescence appears or until the solution is slightly alkaline, as indicated by litmus paper. If a precipitate separates, dissolve it in dilute nitric acid $(1+4)$ and carefully repeat the neutralization with dilute ammonium hydroxide $(1+2)$ until a faint opalescence appears. If no turbidity is visible when the solution is alkaline, add dilute nitric acid $(1+4)$ until the solution is faintly but distinctly acid. Then add $5 \mathrm{ml}$ of dilute hydroshloric acid $(1+9)$, dilute the solution to $400 \mathrm{ml}$ with not water, heat just to boiling, and let stand on a steam bath for 2 to 3 hours, or preferably overnight. Filter on a tight paper containing a little paper pulp and wash once with a small portion of hot water. ${ }^{4}$ Dissolve the precipitate in $25 \mathrm{ml}$ of hot dilute nitric acid $(1+2)$ and transfer the clear solution to a $100-\mathrm{ml}$

${ }^{2}$ At the temperature used in this work perchloric acid is a powerful oxidizing agent and may therefore react with explosive violence if it comes in contact with certain reducing substances, such as organic matter.

3 When large amounts of lead are present bumping may occur, and the conversion of lead bromide to lead perchlorate should be done cautiously. If too much perchloric acid is expelled before complete removal of tin, more perchloric acid should be added.

4 If the iron exceeds $1 \mathrm{mg}$ it interferes when the color of the bismuth-thiourea complex is formed. If necessary, iron may be separated from bismuth at this point by dissolving the precipitate in hydrochloric acid and treating the solution with hydrogen sulfide. volumetric flask. Cool to room temperature, dilute to the mark, and mix.

Transfer a $10-\mathrm{ml}$ aliquot portion of the solution to a $50-\mathrm{ml}$ volumetric flask. ${ }^{5}$ Add $10 \mathrm{ml}$ of dilute nitric acid $(1+5)$ and $15 \mathrm{ml}$ of water and mix. Add $10 \mathrm{ml}( \pm 0.1 \mathrm{ml})$ of the thiourea solution, dilute to the mark, and mix thoroughly. Immediately transfer a suitable portion of the solution to the absorption cell and measure the transmittancy or absorbancy at approximately $425 \mathrm{~m} \mu$, using water in another cell as a reference solution for 100-percent transmittancy or zero absorbancy.

The amount of bismuth is obtained from a standard curve prepared as follows: To five 50-ml volumetric flasks transfer 1.0, 3.0, 5.0, 7.0, and $10.0 \mathrm{ml}$ of the standard bismuth solution and carry a sixth flask through the procedure as a blank. Add $5 \mathrm{ml}$ of the dilute nitric acid $(1+1)$, dilute to $35 \mathrm{ml}$, and add $10 \mathrm{ml}( \pm 0.1 \mathrm{ml})$ of the thiourea solution. Dilute to the mark and mix thoroughly. Measure the transmittancy or absorbancy of the solution as directed for the analysis sample. Plot the absorbancy, $A$, against the respective concentrations on ordinary graph paper, or concentration, $C$, against transmittancy on semilogarithmic paper, using the semilog scale for the percentage, $T$, values. The results obtained with a series of known amounts of bismuth are shown graphically in figure 1.

As the color of the bismuth-thiourea complex has a significant temperature coefficient, the temperature at which the absorbancy measurements of the test solutions and standards are made should not vary more than $2^{\circ} \mathrm{C}$.

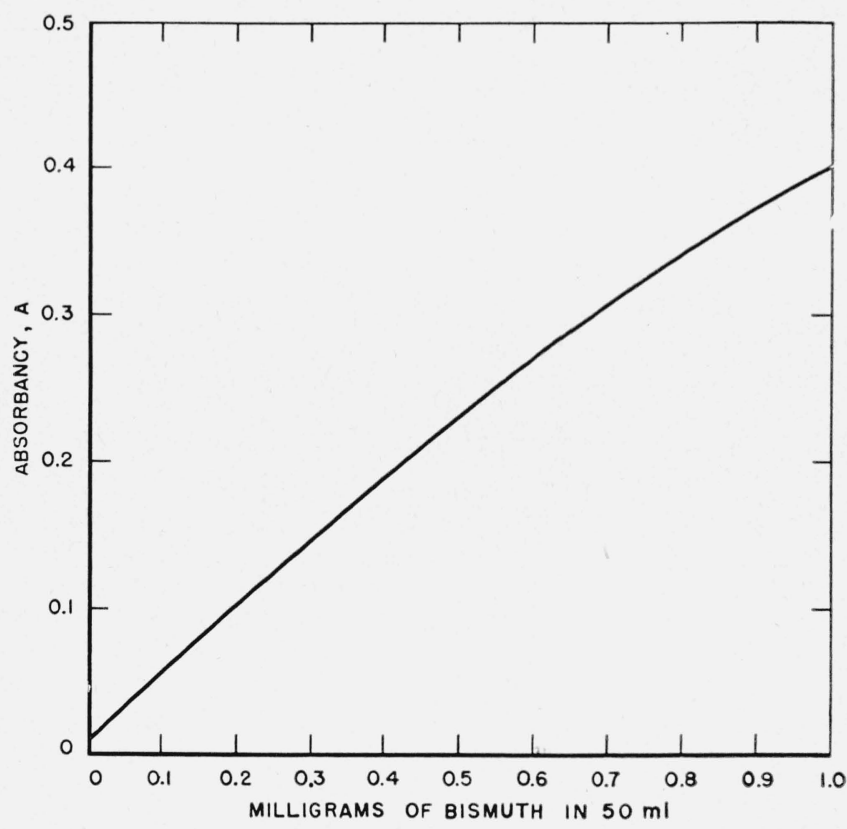

Figure 1. Absorbancy-concentration curve of bismuth-thiourea complex at $425 \mathrm{m \mu}$.

5 If desired, aliquot portions of other size may be used, provided the amount of bismuth and the acidity of the final solutions are within the recommended ranges. 


\section{Results}

The results shown in table 1 indicate the accuracy that can be expected when the complete recommended procedure is applied to known amounts of bismuth.

The data in table 2 indicate the results obtained by applying the recommended procedure to solutions containing known amounts of bismuth, together with other elements likely to be present in lead-base and tin-base alloys.

TABLE 1. Results obtained by applying the recommended procedure to known amounts of bismuth

\begin{tabular}{|c|c|c|}
\hline \multicolumn{3}{|c|}{ Bismuth } \\
\cline { 1 - 1 } Present & Found & Difference \\
\cline { 1 - 1 } & & \\
\cline { 1 - 1 }$m g$ & $m g$ & $m g$ \\
1.00 & 0.95 & -0.05 \\
1.00 & .95 & -.05 \\
5.01 & 5.00 & -.01 \\
5.01 & 4.90 & -.11 \\
10.03 & 9.80 & -.23 \\
10.03 & 9.86 & -.17 \\
a 10.03 & 9.90 & -.13 \\
a 10.03 & 9.80 & -.23 \\
& & \\
\hline
\end{tabular}

a In these experiments 5 - $\mathrm{ml}$ aliquot portions were taken instead of $10 \mathrm{ml}$.

TABLE 2. Results obtained for bismuth in solutions approximating the composition of lead-base and tin-base alloys

\begin{tabular}{|c|c|c|c|c|c|c|}
\hline \multicolumn{3}{|c|}{ Bismuth } & \multirow{2}{*}{ Tin } & \multirow{2}{*}{ Lead } & \multirow{2}{*}{ Copper } & \multirow{2}{*}{$\begin{array}{l}\text { Anti- } \\
\text { mony }\end{array}$} \\
\hline Added & Found & Difference & & & & \\
\hline$m g$ & $m g$ & $m g$ & $m g$ & $m g$ & $m g$ & $m g$ \\
\hline a 10.03 & 9.90 & -0.13 & 860 & 20 & 50 & 70 \\
\hline a 10.03 & 10.00 & -.03 & 860 & 20 & 50 & 70 \\
\hline a 10.03 & 10.00 & -.03 & 860 & 20 & 50 & 70 \\
\hline b 10.03 & 10.00 & -.03 & 860 & 20 & 50 & 70 \\
\hline b 10.03 & 10.15 & +.12 & 860 & 20 & 50 & 70 \\
\hline b 10.03 & 10.15 & +.12 & 860 & 20 & 50 & 70 \\
\hline с 10.03 & 9.85 & -.18 & 50 & 850 & 5 & 100 \\
\hline c 10.03 & 9.85 & -.18 & 50 & 850 & 5 & 100 \\
\hline c 10.03 & 9.90 & -.13 & 50 & 850 & 5 & 100 \\
\hline d 10.03 & 9.95 & -.08 & 50 & 850 & 5 & 100 \\
\hline d 10.03 & 10.00 & -.03 & 50 & 850 & 5 & 100 \\
\hline d 10.03 & 10.00 & -.03 & 50 & 850 & 5 & 100 \\
\hline
\end{tabular}

a Set 1. b Set 2 . c Set 3 . d Set 4 .

TABLE 3. Results obtained for bismuth in tin-base and lead-base alloys

\begin{tabular}{|c|c|c|c|c|c|}
\hline \multirow[b]{2}{*}{ Material } & \multirow[b]{2}{*}{$\begin{array}{l}\text { Weight } \\
\text { of } \\
\text { sample }\end{array}$} & \multicolumn{4}{|c|}{ Bismuth } \\
\hline & & $\begin{array}{l}\text { Certif- } \\
\text { icate } \\
\text { value }\end{array}$ & Found & $\begin{array}{l}\text { Num- } \\
\text { ber of } \\
\text { deter- } \\
\text { mina- } \\
\text { tions }\end{array}$ & Range \\
\hline $\begin{array}{l}\text { Tin-base bearing } \\
\text { metal, NBS Stan- } \\
\text { dard Sample 54c a } \\
\text { Solder, NBS Standard } \\
\text { Sample } 127 \text { b. } \\
\text { Lead-base bearing } \\
\text { metal, NBS Stan- } \\
\text { dard Sample } 53 c^{c}\end{array}$ & ${ }^{g} 7$ & $\begin{array}{c}\text { Percent } \\
0.028 \\
.041\end{array}$ & $\begin{array}{r}\text { Percent } \\
0.026 \\
.041\end{array}$ & 9 & $\begin{array}{c}\text { Percent } \\
0.025 \text { to } 0.027 \\
.039 \text { to } .043 \\
.090 \text { to } .091\end{array}$ \\
\hline
\end{tabular}

Approximate percentages of other constituents:

a $86 \mathrm{Sn} ; 7 \mathrm{Sb} ; 4 \mathrm{Cu} ; 2 \mathrm{~Pb}$.

b $64 \mathrm{~Pb} ; 35 \mathrm{Sn} ; 0.7 \mathrm{Sb} ; 0.1 \mathrm{As}$

c $84 \mathrm{~Pb} ; 10 \mathrm{Sb} ; 5 \mathrm{Sn} ; 0.2 \mathrm{Cu}$.
The data in table 3 indicate the results obtained by applying the recommended procedure to standard samples of tin-base and lead-base alloys.

\section{Discussion}

Volatilization of tin, antimony, and arsenic as the bromides from a perchloric acid solution [3] offers several advantages over volatilization of these elements from a sulfuric acid solution. With perchloric acid, incomplete removal of tin and antimony is indicated by the turbidity of the solution, and the residual lead forms a soluble perchlorate. If the determination or separation of lead is desired, sulfuric acid may be added to the filtrate from the bismuth oxychloride and the solution heated until copious fumes of sulfuric acid appear, to remove the perchloric acid and to precipitate lead sulfate. Copper, nickel, and zinc in the filtrate from the lead sulfate may be determined by suitable methods.

No evidence was found in this work that bismuth was volatilized as the bromide when perchlorichydrobromic acid solutions containing 1 to $10 \mathrm{mg}$ of bismuth were heated to about $200^{\circ} \mathrm{C}$. The color reaction produced by thiourea with bismuth is not sensitive enough to determine with certainty less than $10 \mu \mathrm{g}$ of bismuth in a volume of $50 \mathrm{ml}$. If nitric acid is not present when bismuth is precipitated as the oxychloride in a perchloric acid solution containing lead, an insoluble lead compound will separate. The addition of a small amount of nitric acid prevents the formation of the insoluble lead compound and permits a quantitative separation of bismuth from lead.

Tests of a number of the filtrates from the bismuth oxychloride separation indicated slight, but practically negligible, amounts of bismuth. For example, 30, 10, and $10 \mu \mathrm{g}$ of bismuth were found in the filtrates ${ }^{6}$ when 1,5 , and $10 \mathrm{mg}$ of bismuth were precipitated as the oxychloride.

The presence of $10 \mathrm{mg}$ of silver, $3 \mathrm{mg}$ of copper, and $0.1 \mathrm{mg}$ of iron added as nitrates to $0.2 \mathrm{mg}$ of bismuth as nitrate in a volume of $50 \mathrm{ml}$ does not interfere in the color development of the bismuththiourea complex. These amounts of silver and copper are greater than those encountered ordinarily in the nitric acid solution of the precipitate of bismuth oxychloride. When more than $1 \mathrm{mg}$ of iron is present in the bismuth oxychloride precipitate, the iron must either be removed, or the ferric iron reduced to the ferrous state [4] before the bismuththiourea color is developed. There is no interference in the development of color when $0.25 \mathrm{mg}$ of chlorine as hydrochloric acid is added to $0.2 \mathrm{mg}$ of bismuth as bismuth nitrate in a volume of $50 \mathrm{ml}$ ( $1 \mathrm{mg}$ of bismuth as bismuth oxychloride contains $0.17 \mathrm{mg}$ of chlorine).

The optimum concentration of nitric acid for the development of the yellow color is in the range from 2 to 10 percent by volume [4]. In the described procedure approximately 5 percent by volume of nitric acid is used.

${ }_{6}$ The filtrates were extracted with a carbon tetrachloride solution of dithizone, and bismuth was determined photometrically with thiourea. 
In the recommended procedure all the added thiourea is available for complexing with the bismuth, because the bismuth is isolated from the heavy metals, which also form complexes with thiourea. An attempt was made to determine if there is a minimum amount of thiourea above which the absorbancy of the bismuth-thiourea color is independent of the concentration of the thiourea. Absorption curves were obtained with a Cary Recording Spectrophotometer on five solutions each containing $2.0 \mathrm{mg}$ of bismuth and from 0.25 to $2.5 \mathrm{~g}$ of thiourea in $100 \mathrm{ml}$ of dilute nitric acid $(5+95)$. It was found that the absorbancy, at $425 \mathrm{~m} \mu$, of the bismuth-thiourea color in dilute nitric acid $(5+95)$, is relatively independent of the thiourea concentration when the solution contains 1 percent or more of thiourea. However, for accurate work it is recommended that a pipette be used to measure the volume of the thiourea solution.

A few comparison absorbancy curves, obtained by
John H. Gould with the Cary Recording Spectrophotometer, of the bismuth-thiourea color in dilute nitric acid $(5+95)$ and in perchloric-phosphoric acids [6] showed that the shape of the absorption curve is dependent on the particular acid medium in which the colored complex is developed.

\section{References}

[1] W. F. Hillebrand and G. E. F. Lundell, Applied inorganic analysis, p. 188 (J. Wiley and Sons Inc., New York, N. Y., 1929).

[2] Beverly L. Clarke, L. A. Wooten, and C. L. Luke, Ind. Eng. Chem., Anal. Ed. 8, 411 (1936).

[3] J. I. Hoffman and G. E. F. Lundell, J. Research NBS 22 , 465 (1939) RP1198.

[4] C. Mahr, Z. Anal. Chem. 94, 161 (1933); 97, 96 (1943).

[5] S. L. Tompsett, Analyst 63, 250 (1938).

[6] ASTM Methods of chemical analysis of metals (Am. Soc. Testing Mat., Philadelphia, Pa., 1950).

Washington, March 14, 1951. 